Carlos Clemente Cerri; Brigitte J. Feigl; Marcelo Valadares Galdos; Martial Bernoux; Carlos Eduardo Pellegrino

Cerri. "CARBON STOCK IN SOIL AND GREENHOUSE GAS FLOWS IN THE SUGARCANE AGRO-SYSTEM",

p.203-216. In Luis Augusto Barbosa Cortez (Coord.). Sugarcane bioethanol - R\&D for Productivity and

Sustainability, São Paulo: Editora Edgard Blücher, 2014.

http://dx.doi.org/10.5151/BlucherOA-Sugarcane-SUGARCANEBIOETHANOL_23

\title{
CARBON STOCK IN SOIL AND GREENHOUSE GAS FLOWS IN THE SUGARCANE AGRO-SYSTEM
}

\author{
Carlos Clemente Cerri, Brigitte J. Feigl, Marcelo Valadares Galdos, \\ Martial Bernoux and Carlos Eduardo Pellegrino Cerri
}

\section{INTRODUCTION}

Brazil is the world's largest sugarcane producer (FAOSTAT, 2007), with an area of approximately 7 million hectares, and a production of 550 million tons (2006/2007 harvest season), which represents a $13 \%$ increase in planted area and $16 \%$ over the previous harvest season (UNICA, 2008). From these 7 million hectares, 3.7 are located in the São Paulo state, representing $52.8 \%$ of the country's area, and $58 \%$ of the domestic production (CONAB, 2008). Estimates from Ministério da Agricultura, Abastecimento e Pecuária (MAPA, 2007) indicate a significant increase in the cultivated area for the next 10 years, to about 10.3 million hectares, as a result of potential demand from several countries interested in using ethanol as fuel, either to comply with the Kyoto Protocol, (mostly environmental considerations) or geopolitical and security of supply issues (MACEDO et al., 2008).

In the sugarcane production system, burning tops and leaves before harvesting has been a common practice, to make stalks cutting, loading and transportation operations easier. The burning process produces the emission of gases like $\mathrm{CO}_{2}$, $\mathrm{CH}_{4}$, and $\mathrm{N}_{2} \mathrm{O}$, responsible for the greenhouse effect. Such practice also releases soot, which causes inconveniences as well as health hazards to neighboring populations (CANÇADO et al., 2006).

Public policy banning sugarcane burning, together with the development of more efficient harvesting machinery, has favored harvesting of "raw" sugarcane (that is, unburned sugarcane), leaving the trash on the ground. In the São Paulo state, where more than half of the Brazilian sugarcane is produced, mills and distilleries are required by law (Decree n. 10547, of May $2^{\text {nd }}, 2000$, complemented by Decree n. 11241, of September $19^{\text {th }}, 2002$ ) to progressively phase out sugarcane burning. There are projections that $80 \%$ of the planted area in the Center-South region of Brazil - where most of the production is located - will be harvested unburned by 2014 (MACEDO, 2004). Brazil has accumulated considerable know-how in sugarcane handling that adopts trash burning; however, as it is relatively recent, there is still little information on the effect of handling unburned cane on the soil characteristics and other environmental impacts (GALDOS, 2007).

Recent studies have pointed out that leaving the trash on the soil will alter its physical, chemical, and biological properties. Various authors have studied the effect of the trash in the nitrogen dynamics in the sugarcane agro-system, focusing on issues such as immobilizing soil nitrogen by the microbiota after the addition of high $\mathrm{C}>\mathrm{N}$ ratio residues, and making nitrogen available from the trash for absorption by the plant (BASANTA et al., 2004; GAVA et al., 2005). Significant effects of leaving the trash on the soil's physical factors, such as spatial variability of temperature and moisture (DOURADO-NETO et al., 1999), soil density (TOMINAGA et al., 2002), aggregate stability, and infiltration speed (CEDDIA, 1999; GRAHAM et al. 2002), in addition to the reduction of gas emissions, if compared to the traditional harvest system (ANDREAE, 2001) have been reported. If 
most of this trash is progressively mineralized over the year, part of it is capable of remaining longer in the system, resulting in a higher organic matter (OM) content in the soil. Various experiments have shown correlation between leaving the sugarcane trash and the increase in the soil total carbon content, influenced by variables such as time the unburned cane system was adopted, soil texture, and extent to which the soil was ploughed upon reforming the sugarcane plantation (GRAHAM et al., 2002, CANELLAS et al., 2003, ROBERTSON, 2003, CERRI et al., 2004).

As for the organic matter (OM) content, it is known that tropical climate soils have an average of 1-2\% in the first $20 \mathrm{~cm}$ of depth, which can be divided into fragile and persistent compartments. In the fragile fraction, most of the elements essential for plant development are found, part of N, P, and $\mathrm{C}$ present in the soil, and all the microbial population. The persistent fraction - the more advanced decomposition stage, in turn represents between $70 \%$ and $90 \%$ of the total soluble OM, contributing with about $98 \%$ of the organic form C, and 50\% to $97 \%$ of the humic substances.

As a renewable source of energy, sugarcane has one the highest yields, in terms of efficiency and flexibility, producing solid, liquid, and gaseous fuels (RIPOLI et al., 2000). It offers opportunities for mitigating global warming by replacing fossil fuels, without requiring excessive subsidies or the development of expensive infrastructures. Additionally, the wide application of conservationist agricultural practices may further increase the environmental offset of ethanol relative to fossil fuels. However, the quantification of this effect, which has been done in a sporadic and haphazard manner, has is of a strategic relevance for Brazil. A synthesis of the key information available on the matter will be presented next.

\section{MITIGATION OF GLOBAL WARMING: QUANTIFICATION OF PARAMETERS IN THE SOIL-PLANT-ATMOSPHERE INTERACTION}

A survey of the contribution of vegetal biomass, carbon stock in the soil, and greenhouse ef- fect gases (GHG) emissions was carried out on two sugarcane plantations in the Ribeirão Preto area, São Paulo state. The region has a tropical climate, with average yearly temperature of $22.9{ }^{\circ} \mathrm{C}$, and average rainfall of $1560 \mathrm{~mm}$ yearly, concentrated in summertime.

Situation 1: The clayous soil (70-80\% clay) of the areas surveyed was classified as Red Dystrophic Latosol (EMBRAPA, 2006), Orthic Ferrasol (FAO, 2006) or Typical Haplugow (SOIL SURVEY STAFF, 1999). On the surface $(0-10 \mathrm{~cm})$, the $\mathrm{pH}$ $\mathrm{CaCl}_{2} \mathrm{pH}$ is 4.7 , cation exchange capacity is $9 \mathrm{cmol}$ $(+) / \mathrm{kg}^{-1}$, and the exchanges complex bases saturation ratio is around 30\%. For 50 years, until 1995, harvest was done in the traditional way, preceded by burning. From 1995 on, the area was divided into 12 parts: six of them were maintained under the same handling (burning), while the other six parts had mechanized harvesting, and the unburned tops and leaves and tips left on the soil surface (unburned cane treatment - Figure 1). Each part was randomly assigned to either type of handling. The field was fertilized with NPK, formulation $25-125-125 \mathrm{~kg} / \mathrm{ha}$ every six years on the occasion the sugarcane field was reformed, and with 85-50-100 kg/ha at every resprout, i.e. every year, since the cultivation cycle lasts 12 months. The variety of sugarcane planted was the SP 80185 , with regular spacing of $1.50 \mathrm{~m}$ between rows.

Situation 2: The sandy soil (10-15\% clay) of the parts studied was classified as Sand-Quartz Neosol (EMBRAPA, 2006), Arenosol (FAO, 2006), or Quartzipsamment (SOIL SURVEY STAFF, 1999). The variety of sugarcane planted was the RB 7851-48, with regular spacing of $1.50 \mathrm{~m}$ between rows. The survey was organized as in Situation 1.

\section{Contribution of vegetal biomass in the soil}

Quantification of the vegetal biomass contribution in the soil was done collecting material deposited within a known area (Figure 2), randomly distributed in the planting midline.

In parts where sugarcane was burned before harvesting, there was no contribution of vegetal biomass in the soil. Conversely, in the unburned 

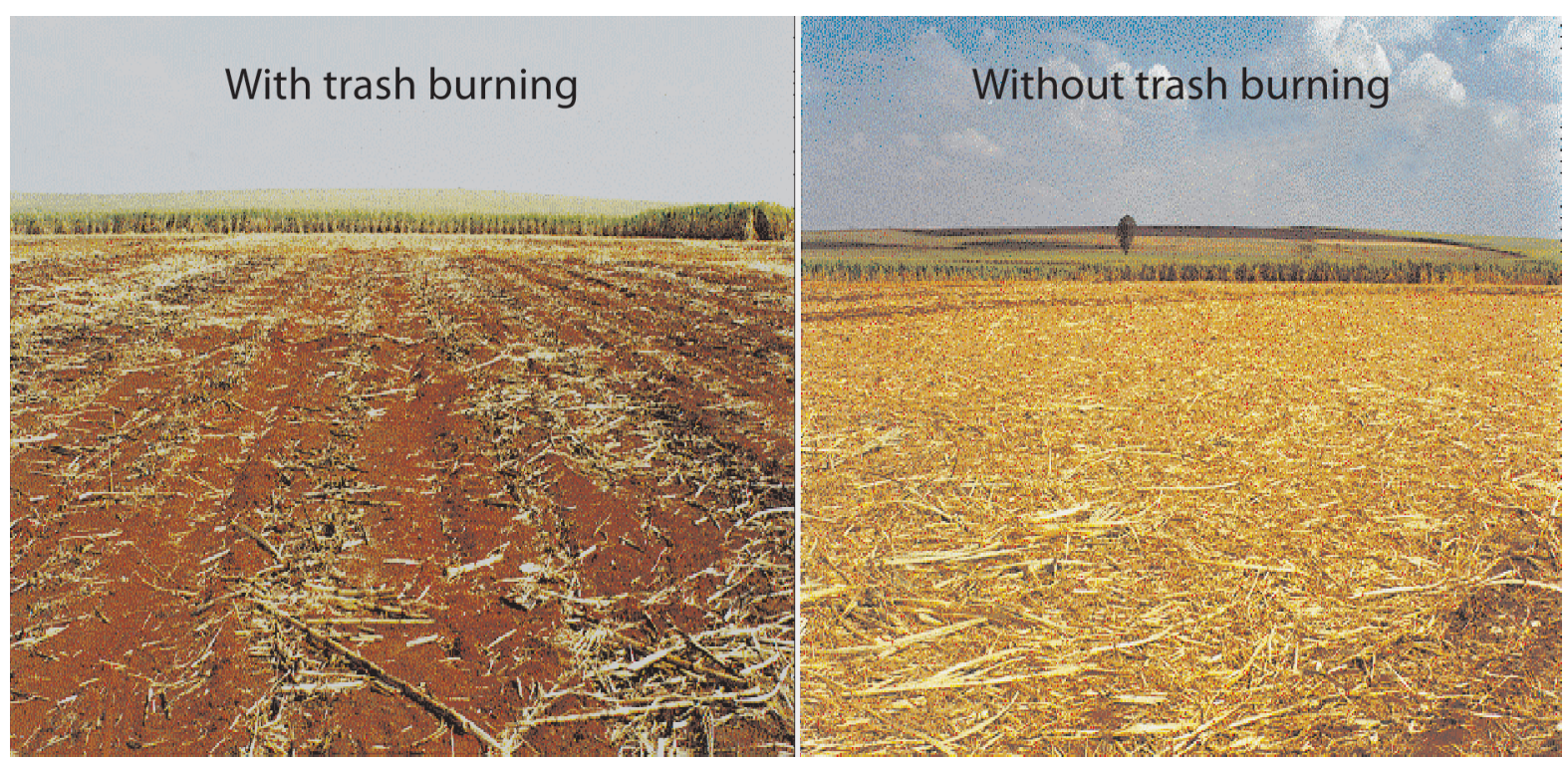

FIGURE 1 Soil surface in sugarcane areas harvested with and without trash burning.

cane harvest, the average vegetal biomass production in the 1996-2000 period was 13.9 t/ha in Situation 1, and 12.9 t/ha in Situation 2 (Table 1).

CAMPOS (2003), in an agronomic study of Situation 1 , assessed the effect of different sugarcane varieties in the vegetal biomass annual production on the occasion of the harvest: the most commonly used variety for producing sugar (SP 80-1816) and three other selected varieties, according to their vegetal biomass production capacities: RB 82-5335 (high production), RB 83-5486 (average production), and RB 85-5453 (low production). No significant difference was observed between the parts harvested without burning, where the varieties were maintained for four years. The quantity of residual trash after three years (before the fourth harvest) had little variation, from $6.5 \mathrm{t} \mathrm{DM} /$ ha to $7.5 \mathrm{t} \mathrm{DM} / \mathrm{ha}$, which corresponds to a stock of 2.3 to $2.7 \mathrm{t} \mathrm{C/ha}$. The trash stocks, before harvest in Situation 1 , are shown on Table 2.

Regarding Situation 2, only one collection was made in 1999 before the harvest. The remaining

TABLE 1 Culture productivity and annual leftover of vegetal biomass during harvest in the two situations studied, in t/ha.

\begin{tabular}{|c|c|c|c|c|c|c|}
\hline \multirow{2}{*}{ Year } & \multicolumn{3}{|c|}{ Situation 1} & \multicolumn{3}{|c|}{ Situation 2} \\
\hline & Productivity & Leftover & $\%$ & Productivity & Leftover & $\%$ \\
\hline 1996 & 104 & 15.7 & 15.1 & 132 & 10.5 & 8.0 \\
\hline 1997 & 114 & 12.8 & 11.2 & 96 & 16.8 & 17.5 \\
\hline 1998 & 99 & 11.3 & 11.4 & 68 & 11.4 & 16.8 \\
\hline 1999 & 82 & 14.5 & 17.7 & 43 & - & - \\
\hline 2000 & 78 & 15.2 & 19.5 & - & - & - \\
\hline Avg. & $95.4 \pm 13.5$ & $13.9 \pm 1.6$ & $15.0 \pm 3.3$ & $84.8 \pm 33.1$ & $12.9 \pm 2.8$ & $14.1 \pm 4.3$ \\
\hline
\end{tabular}

* yields and leftovers were determined by Copersucar (Sugarcane project final report of the 1999/2000 harvest season RT \#961, 2000). 


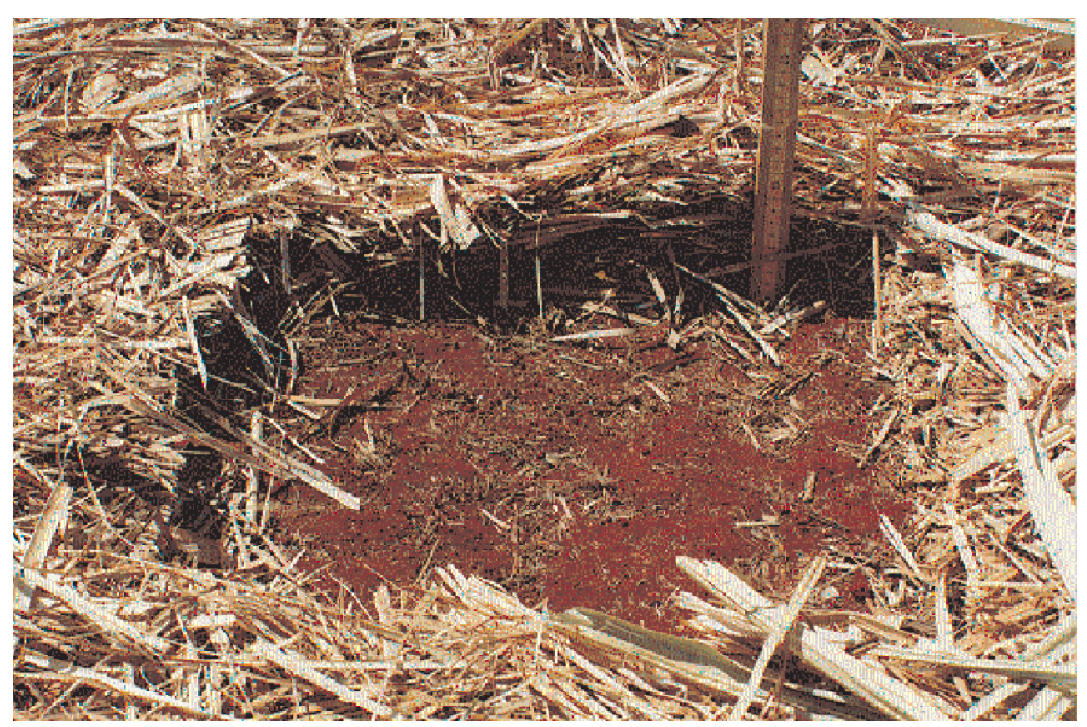

FIGURE 2 Trash left on the soil surface under sugarcane harvested without burning.

trash contained $3.58 \pm 0.39 \mathrm{t} \mathrm{DM} / \mathrm{ha}$ (i.e. around $1.35 \mathrm{t} \mathrm{C} / \mathrm{ha}$ and $\mathrm{C} / \mathrm{N}$ ratio $=65)$, and represented 12.5\% of the accrued entries since 1996.

Based on the quantities of vegetal biomass deposited after the harvest (Table 1) and residual before harvest (Table 2), it is possible to study the yearly material decay dynamics, and calculate the average decay rate. The simple hypothesis of an exponential type decay occurring may be made over one year, the quantity of vegetal biomass on a certain date $t$ is obtained by the formula $\mathrm{Q}(\mathrm{t})=\mathrm{Qo}$ $\mathrm{e}^{-\mathrm{kt}}$, considering that on a first moment the decay speed is the same every year, the data available allows us to write the following equations:

For the 2000 harvest season:

$$
5.59=14.5^{\mathrm{e}-\mathrm{k}}+11.3^{\mathrm{e}-2 \mathrm{k}}+12.8^{\mathrm{e}-3 \mathrm{k}}+15.7^{\mathrm{e}-4 \mathrm{k}} .
$$

For the 1999 harvest season:

$$
4.46=11.3^{\mathrm{e}-\mathrm{k}}+12.8^{\mathrm{e}-2 \mathrm{k}}+15.7^{\mathrm{e}-3 \mathrm{k}} .
$$

For the 1998 harvest season:

$$
5.97=12.8^{\mathrm{e}-\mathrm{k}}+15.7^{\mathrm{e}-2 \mathrm{k}} \text {. }
$$

The mathematical solutions of the equations are, respectively, $\mathrm{k}=1.23635 /$ year, $\mathrm{k}=1.2814$ /year, and $\mathrm{k}=1.1039 /$ year. These values calculated for $\mathrm{k}$ vary due to errors associated to the measurement of vegetal biomasses weight, and the spatial variability of deposits. Decay speed depends on biologic activity, which is strongly dependent on temperature and moisture conditions. Such conditions may vary from one year to another. For this first approximation, a weighted average decay factor of $\mathrm{k}_{\text {avg }}$ for the period 1998-2000 of 1.222/year or yet $0.0034 /$ day may be considered. This decay coefficient corresponds to one average half-life (half-life $=\ln 2 / \mathrm{k}$ ) of 0.567 per year, or 207 days. Integrating the yearly average decay equations it is possible to calculate the average stock of vegetal biomass (ASVB) present in the soil for each year, therefore being, in the first year, ASVB $=8 \mathrm{t} \mathrm{DM}$, and in the fifth year, 11.3 $\mathrm{t} \mathrm{DM}$, with an average of 10.4 t DM (about 4.6 t C) for the five-year period after planting the sugarcane.

Measurements were likewise taken over the 1999/2000 period between two successive harvest seasons (Figure 3). Simplifying the decay model, reducing it to one sole global equation, it is possible to calculate a decay coefficient of $0.0027 /$ day and an average half-life around 257 days for the referring period corresponding to an EML around 9 t DM.

These results show that, after harvesting without burning, an important stock of $\mathrm{C}$, to the tune of tons per hectare, is formed on the soil. This behavior is quite fragile, and may be significantly 
TABLE 2 C stocks and C/N ratios in the vegetal biomass in Situation 1, after one year of decay, before the harvest.

\begin{tabular}{|l|c|c|c|c|}
\hline $\begin{array}{c}\text { Period } \\
\text { Year }\end{array}$ & $\begin{array}{c}\text { Dry matter intake } \\
\text { t DM/ha }\end{array}$ & Carbon stock t C/ha & C/N ratio & $\begin{array}{c}\text { Accrued intakes } \\
\text { since 1996 } \\
\%\end{array}$ \\
\hline 1998 & $5.97 \pm 1.55$ & 2.55 & N/A & 20.9 \\
\hline 1999 & $4.46 \pm 0.70$ & 1.61 & 51 & 11.2 \\
\hline 2000 & $5.59 \pm 2.36$ & 2.36 & N/A & 10.3 \\
\hline
\end{tabular}

reduced, for instance, by an accidental fire. Likewise, it is not known what will happen after the sugarcane field reform process, performed every 5-7 years, when the soil is plowed and graded usually for planting sugarcane.

\section{Carbon stock in the soil}

The soil samples were collected in March 1999 , at the end of the rainy summer, one week before the fourth harvest. In each experimental part, six mini-trenches (three of them on central lines, and three on the interlines) samples were taken at 0-5, 5-10, and 10-20 cm depth. Samples were dried and sieved to $2 \mathrm{~mm}$. Standard-size samples were taken to quantify the $\mathrm{C}$ content using a dry method, with an auto-analyzer Leco CN-2000, and to determine soil density by means of cylinders (Figure 4), necessary for calculating carbon stock.

The quantity of vegetal biomass accumulated and returned in Situation 1 from the three previous harvests is $39.8 \mathrm{t} \mathrm{DM} / \mathrm{ha}$, which represents around 17 t C/ha. Differences in C stock between burned and unburned cane $(\Delta \mathrm{C})$ are significant only for the $0-5 \mathrm{~cm}$ layer. The increase in stocked $\Delta \mathrm{C}$ in unburned cane in the $0-20 \mathrm{~cm}$ layer represents $38 \%$ of the $\mathrm{C}$ returned by the vegetal biomass. Around half of it is in the $0-5 \mathrm{~cm}$ layer, where the increase in $\mathrm{C}$ represents $18.5 \%$ of the $\mathrm{C}$ returned by the vegetal biomass. This value is higher than the $\mathrm{C}$ stock present in the residual material (1.61 t $\mathrm{C} / \mathrm{ha}$ ), which represents $9.5 \%$ of the $\mathrm{C}$ returned as

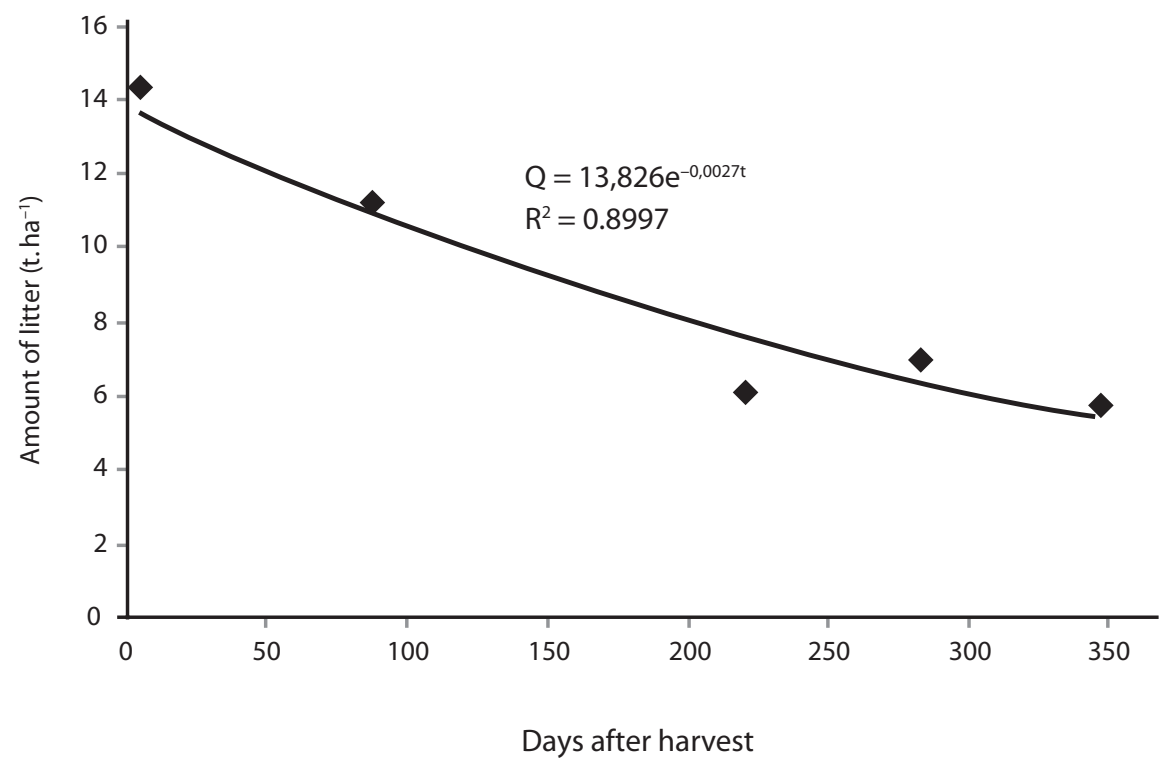

FIGURE 3 Variation in the vegetal biomass quantity during a culture cycle (1999-2000) in Situation 1. 


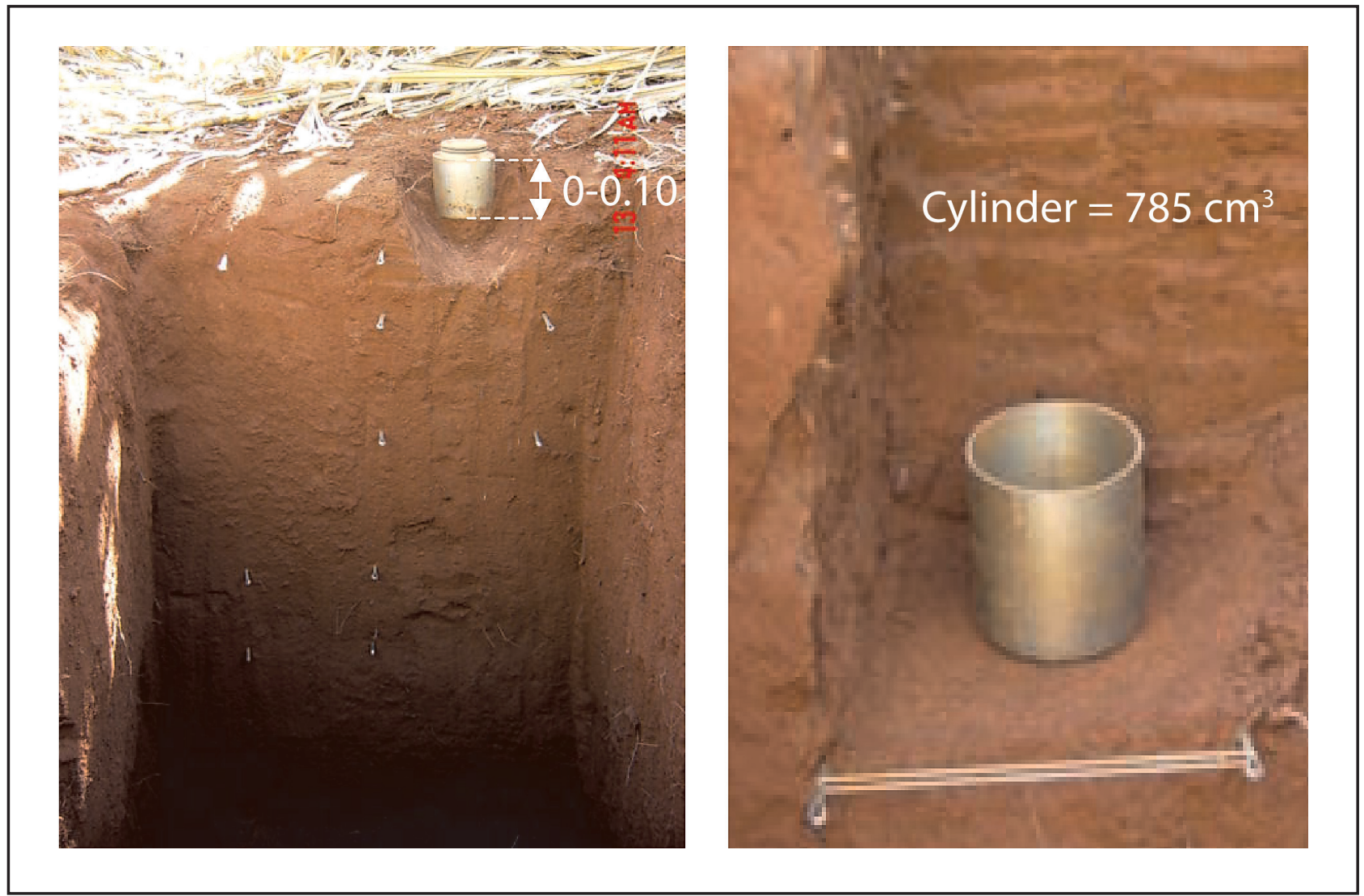

FIGURE 4 Illustration of soil samples collection for analyzing carbon content and determining soil density (cylinders).

TABLE 3 Carbon stocks in the soil in Situations 1 and 2 after 4 years' cultivation in the burned and unburned cane systems.

\begin{tabular}{|c|c|c|c|c|c|c|}
\hline \multirow{3}{*}{$\begin{array}{c}\text { Layer } \\
\mathrm{cm}\end{array}$} & \multicolumn{6}{|c|}{ Carbon stock (t C/ha) } \\
\hline & \multicolumn{3}{|c|}{ Situation 1} & \multicolumn{3}{|c|}{ Situation 2} \\
\hline & Burned cane & Unburned cane & $\Delta C$ & Burned cane & Unburned cane & $\Delta C$ \\
\hline $0-5$ & 11.72 & 14.87 & 3.15 & 4.84 & 7.68 & 2.84 \\
\hline $5-10$ & 12.43 & 14.41 & 1.98 & 5.35 & 5.92 & 0.57 \\
\hline $10-20$ & 24.80 & 26.17 & 1.37 & 10.80 & 12.26 & 1.46 \\
\hline $0-10$ & 24.15 & 29.28 & 5.13 & 10.19 & 13.60 & 3.41 \\
\hline $0-20$ & 48.95 & 55.45 & 6.50 & 20.99 & 25.86 & 4.87 \\
\hline
\end{tabular}

vegetal biomass. For Situation 2, sandy, the excess C stoked in unburned cane in the soil $(0-20 \mathrm{~cm})$, and the stocks in the vegetal biomass represent respectively $29.5 \%$ and $8.2 \%$ of the $\mathrm{C}$ introduced into the system (FELLER, 2001).

In Situation 1, the unburned cane system stores $6.5 \mathrm{t}$ C more than the burned cane system in the 0-20 cm layer, which represents a stocking rate of $1,625 \mathrm{~kg} \mathrm{C} / \mathrm{ha} / \mathrm{year}$ for the first four years. It is interesting to note that for the sandy soil in Situation 2 , the increase $(\Delta \mathrm{C}=4.87 \mathrm{t} \mathrm{C/ha)}$ is of the same magnitude as in the clayous soil, even the initial stocks in the soil being quite different.

Other results for the 0-20 cm layer, obtained in the same region of Brazil in studies of commercial parts, for burned and unburned cane, were 
TABLE 4 Yearly stocking rates observed in the $0-20 \mathrm{~cm}$ layer of the soil under commercial sugarcane planting in the Center-West region of the São Paulo state.

\begin{tabular}{|c|c|c|c|c|c|c|}
\hline Part & Brazilian soils classification & Clay & $\begin{array}{c}\text { Carbon } \\
\text { stock } \\
\text { (burned } \\
\text { cane) }\end{array}$ & $\begin{array}{c}\text { Carbon } \\
\text { stock } \\
\text { (unburned } \\
\text { cane) }\end{array}$ & $\begin{array}{c}\text { Time } \\
\text { unburned } \\
\text { cane }\end{array}$ & $\begin{array}{c}\text { Yearly } \\
\text { accumulation } \\
\text { rate }\end{array}$ \\
\hline & & $\%$ & \multicolumn{2}{|c|}{ t C/ha } & years & t C/ha.year \\
\hline \multicolumn{7}{|c|}{ Usina São Martinho (Pradópolis, SP) } \\
\hline$A$ & Dis. Red Latosol & $70-80$ & 42.11 & 43.61 & 3 & 0.50 \\
\hline B & Dis. Red Latosol & $70-80$ & 42.11 & 40.98 & 5 & -0.23 \\
\hline \multicolumn{7}{|c|}{ Usina Santa Luiza (Matão, SP) } \\
\hline C & Chromic Claysol & $18-25$ & 23.88 & 28.93 & 4 & 1.26 \\
\hline $\mathrm{D}$ & Red Yellow Latosol & $32-36$ & 40.01 & 43.91 & 12 & 0.33 \\
\hline
\end{tabular}

described by FELLER (2001), and are summarized on Table 4.

FELLER (2001) shows that, at the time of implementing the burned and unburned cane alternatives in part B, it was likely that there were initial differences that influenced the results. Furthermore, referring to part $\mathrm{D}$, there was a reform revolving the soil, and probably the residues were buried. From these results, it is possible to notice that for the 3-5 periods, the increases in $\mathrm{C}$ stock in the soil go from 0.5 to $1.6 \mathrm{t} \mathrm{C/ha/year,} \mathrm{but} \mathrm{they} \mathrm{are} \mathrm{strongly} \mathrm{mitigated}$ on the mid term with the start of sugar field reform, and/or may have a tendency to reach balance.

Few results were published comparing the harvest systems with burned and unburned cane. GRAHAM et al. (2002) studied, in South Africa, the impact of trash management with burned and unburned cane, left on site or removed, and of fertilization on the soluble $\mathrm{OM}$ in a long term study (59 years). The $\mathrm{C}$ stock in the 0-30 layer of the fertilized system with unburned cane was 137.7 t C/ha. Though in the same system with burned cane the result measured was $132.6 \mathrm{t}$ C/ha, the difference was not meaningful. On the other hand, significant differences were reported for the superficial 0-10 cm layer, however the figures are not provided in the paper. Whatever are the differences in stock, they translate into a very low annual growth, not surpassing 0.09 t C/ha.year.

In Australia (tropical climate, average yearly rainfall - 4,300 mm, 15-20 t DM residues per year,
NOBLE et al. (2003) noticed an increase of $4.8 \mathrm{t}$ $\mathrm{C} /$ ha in the $0-10 \mathrm{~cm}$ layer, after seven years of unburned cane handling, i.e., an average sticking rate of $0.69 \mathrm{t}$ C/ha/year. Also in Australia, THORBURN et al. (2000) studied five different situations with burned and unburned cane, over a period of 3 to 18 years. In all five situations, C stocks for unburned cane were statistically higher than burned cane only in the 0-5 cm layer. They found a maximum increase of the C content of $0.24 \%$ for the $0-10$ $\mathrm{cm}$ layer of a clayous soil, after seven years of unburned cane culture. Considering an arbitrary density of $1.2 \mathrm{~g} / \mathrm{cm}^{3}$, this increase corresponds to a yearly increase rate of about $0.4 \mathrm{t} \mathrm{C} /$ ha.year.

\section{Greenhouse Effect Gases - GEG}

Greenhouse effect gases $\left(\mathrm{CH}_{4}\right.$ and $\left.\mathrm{N}_{2} \mathrm{O}\right)$ flows were measured in a vegetal biomass/soil/atmosphere in incubation chambers built from a circular base having $29 \mathrm{~cm}$ diameter attached to the ground, and a lid with an orifice that allowed collecting the accumulated gases. Six chambers were used in each burned and unburned cane handling. Gas samples were taken with $20 \mathrm{ml}$ syringes 0, 5, 10, and 20 minutes after the lid was closed, which allowed following changes in GHG concentration and the calculation of the flows in the soil-trashatmosphere system (Figure 5).

Samples were taken three times a day, at 7 AM, 12 noon, and 5 PM. Next, the syringes were 


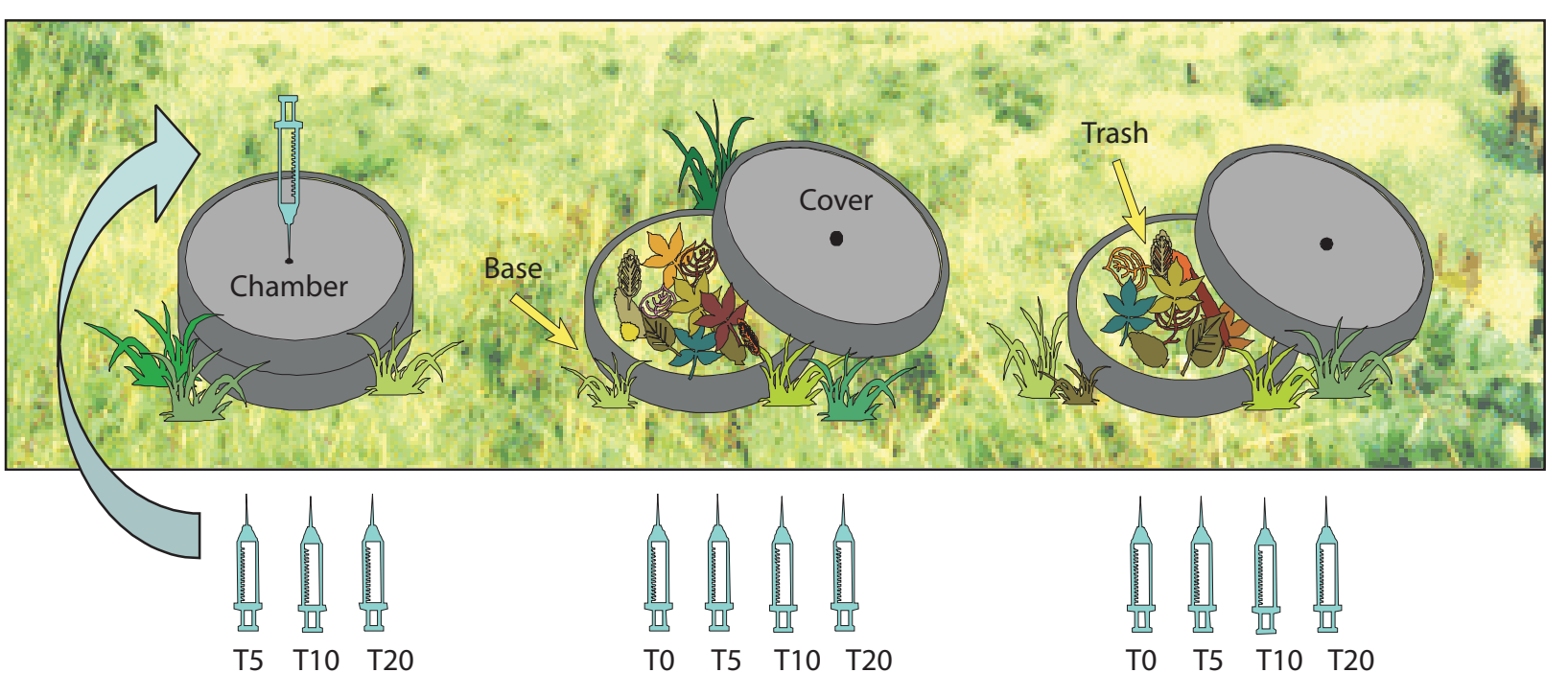

FIGURE 5 System used for collectting sample of gas emission.

taken to the laboratory to measure $\mathrm{CH}_{4}$ and $\mathrm{N}_{2} \mathrm{O}$ concentration, using a Shimadzu, CR501 chromatograph (Figure 6).

\section{Yearly $\mathrm{CH}_{4}$ flow from soils}

Methane flows may be positive (produced by soils) or negative (consumed by soils) as a function of the bacterial community present, expressed according to the environmental conditions. The results from measurements taken in the burned and unburned cane handling systems in Situation 1, over the agricultural year 1999/2000, are summarized in Figure 7.
The burned cane handling presents constant methanotrophy (oxidation of $\mathrm{CH}_{4}$ by the soil microbial community) throughout the year, at rates between -4.9 and $-48.8 \mathrm{~g} \mathrm{CH}_{4} / \mathrm{ha} /$ day, with an average value of $-16.9 \mathrm{~g} \mathrm{CH}_{4} /$ ha.day. This average value corresponds to a yearly consumption of $6.17 \mathrm{~kg} \mathrm{CH}_{4} /$ ha in the burned cane system. In the unburned cane handling, variation amplitude is higher, with results indicating methanotrophy of up to $-24.6 \mathrm{~g} \mathrm{CH}_{4} /$ ha.day to methanogenesis $\left(\mathrm{CH}_{4}\right.$ generation by the microbial community in the soil) of $10.1 \mathrm{~g} \mathrm{CH}_{4} /$ ha/day. However, the methanotrophy process prevails, with an average oxidation of $8 \mathrm{~g}$ $\mathrm{CH}_{4} /$ ha/day, which corresponds to an annual total
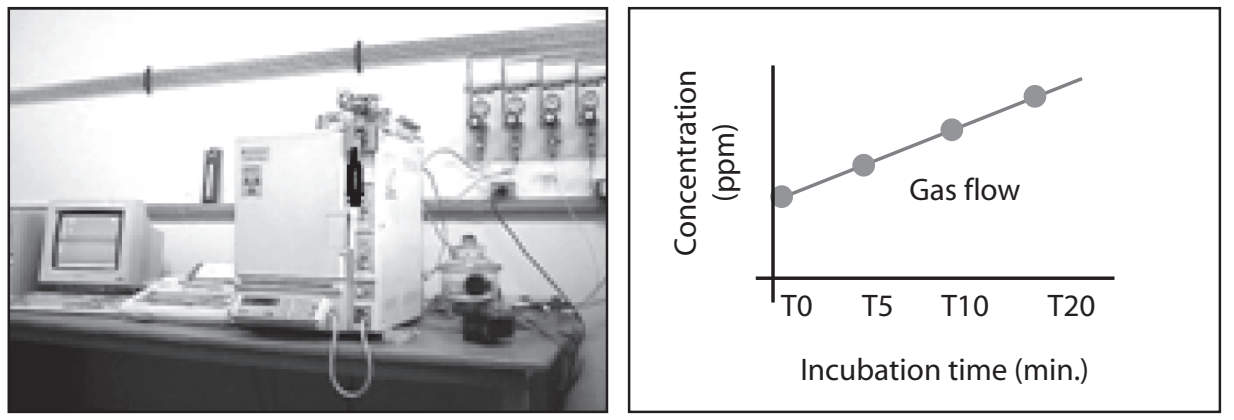

FIGURE 6 Gaseous phase chromatograph and gas flow schematics. 


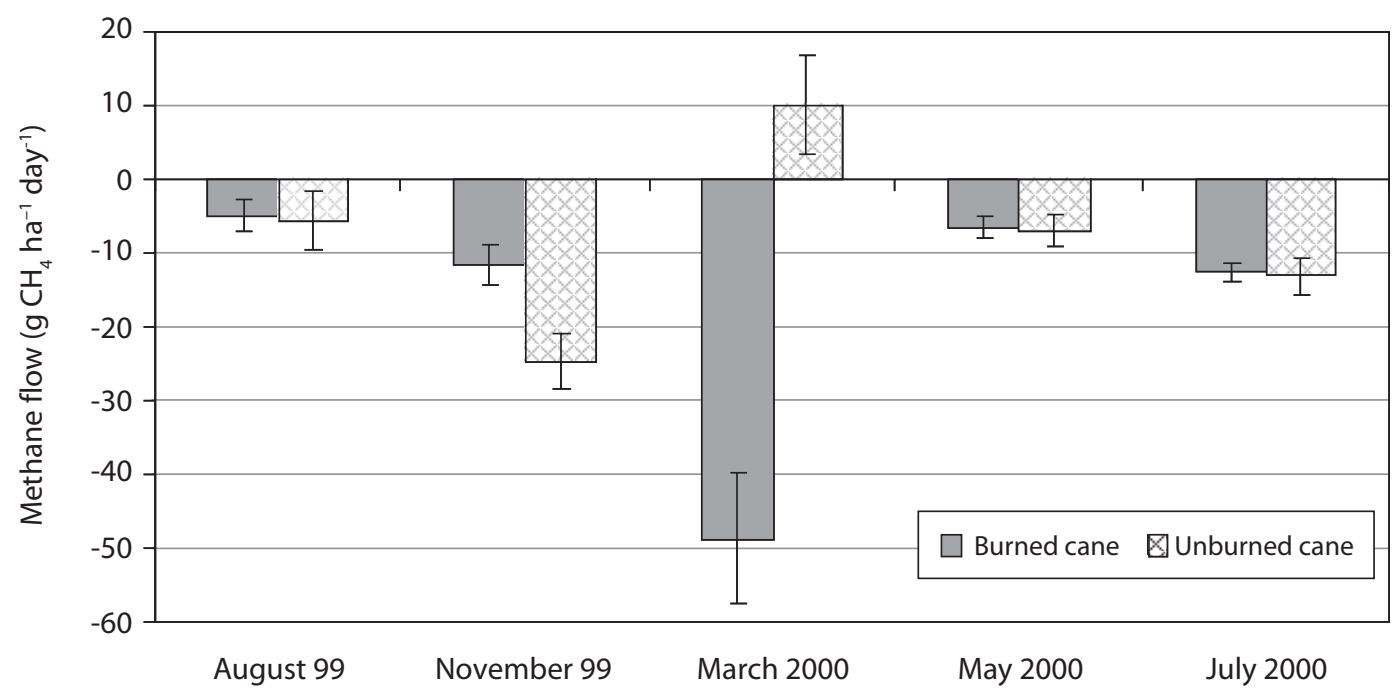

FIGURE 7 Methane flow in burned and unburned cane systems. Bars represent the standard error (standard deviation divided by the number of observations).

of $2.92 \mathrm{~kg} \mathrm{CH} 4 / \mathrm{ha}$. In a measurement taken one week after the August 2000 harvest, the burned cane system presented an oxidation rate of $21.6 \mathrm{~g}$ $\mathrm{CH}_{4} /$ ha/day, while the unburned cane system was emitting $38.4 \mathrm{~g} \mathrm{CH}_{4} / \mathrm{ha} /$ day.

SCHWEIZER (2000) measured during three months of a rainy summer (November through January) the GHG flows in sugarcane fields located in Piracicaba (São Paulo state), $200 \mathrm{~km}$ south of Situation 1 . The author calculated average oxidation rates of $3.9,0.1$, and $1.1 \mathrm{~g} \mathrm{CH}_{4} /$ ha/day in each burned cane harvested field after, respectively, 28, 66 , and 21 years.

\section{Yearly $\mathrm{N}_{2} \mathrm{O}$ flow from soils}

Complex interactions between soil properties, climatic factors, and agricultural practices determine the nitrous oxide emission rate during the nitrification, and mostly denitrification processes, resulting in a wide spatial and timely variability (GRANLI, 1994).

For the burned cane system, average flows vary from -0.3 to $22.6 \mathrm{~g} \mathrm{~N}_{2} \mathrm{O} /$ ha/day, and present an average yearly value of $11 \mathrm{~g} \mathrm{~N}_{2} \mathrm{O}$ /ha.day. In the unburned cane system, flows present wider variations, with extremes from -6.8 and $23 \mathrm{~g} \mathrm{~N}_{2} \mathrm{O} / \mathrm{ha} /$ day, and an annual average of $15.7 \mathrm{~g} \mathrm{~N}_{2} \mathrm{O} /$ ha/day. Negative $\mathrm{N}_{2} \mathrm{O}$ flows are unusual; however, other authors have already observed this phenomenon (BOWDEN et al., 1991; YAMULKI et al., 1995). During one year, the burned and unburned cane systems emitted, in average, $4 \mathrm{~kg} \mathrm{~N}_{2} \mathrm{O} / \mathrm{ha}$ and 5.7 kg $\mathrm{N}_{2} \mathrm{O}$ /ha, respectively (Figure 8).

SCHWEIZER (2000) also measured $\mathrm{N}_{2} \mathrm{O}$ flows, and attributed average values of 7, 3, 10, and 7.7 $\mathrm{g} \mathrm{N}_{2} \mathrm{O} /$ ha/day, for each area harvested with burned cane for 28, 66, and 21 years, respectively. Few results were published considering $\mathrm{N}_{2} \mathrm{O}$ flows in the unburned cane system. DALAL et al. (2003) quote from the works of WEIER (2000), reporting average emission values of $21 \mathrm{~g} \mathrm{~N}_{2} \mathrm{O} / \mathrm{ha} /$ day for unburned cane, and $17.8 \mathrm{~g} \mathrm{~N}_{2} \mathrm{O} / \mathrm{ha} /$ day for burned cane.

It is necessary to study in more detail $\mathrm{N}_{2} 0$ emissions in burned and unburned cane systems, mostly at the time of applying fertilizers, burning the vegetal biomass, and reforming the sugarcane fields.

\section{$\mathrm{CH}_{4}$ and $\mathrm{N}_{2} \mathrm{O}$ flow during vegetal biomass burning}

Every combustion of organic residues comprises emissions of methane and nitrous oxide. 


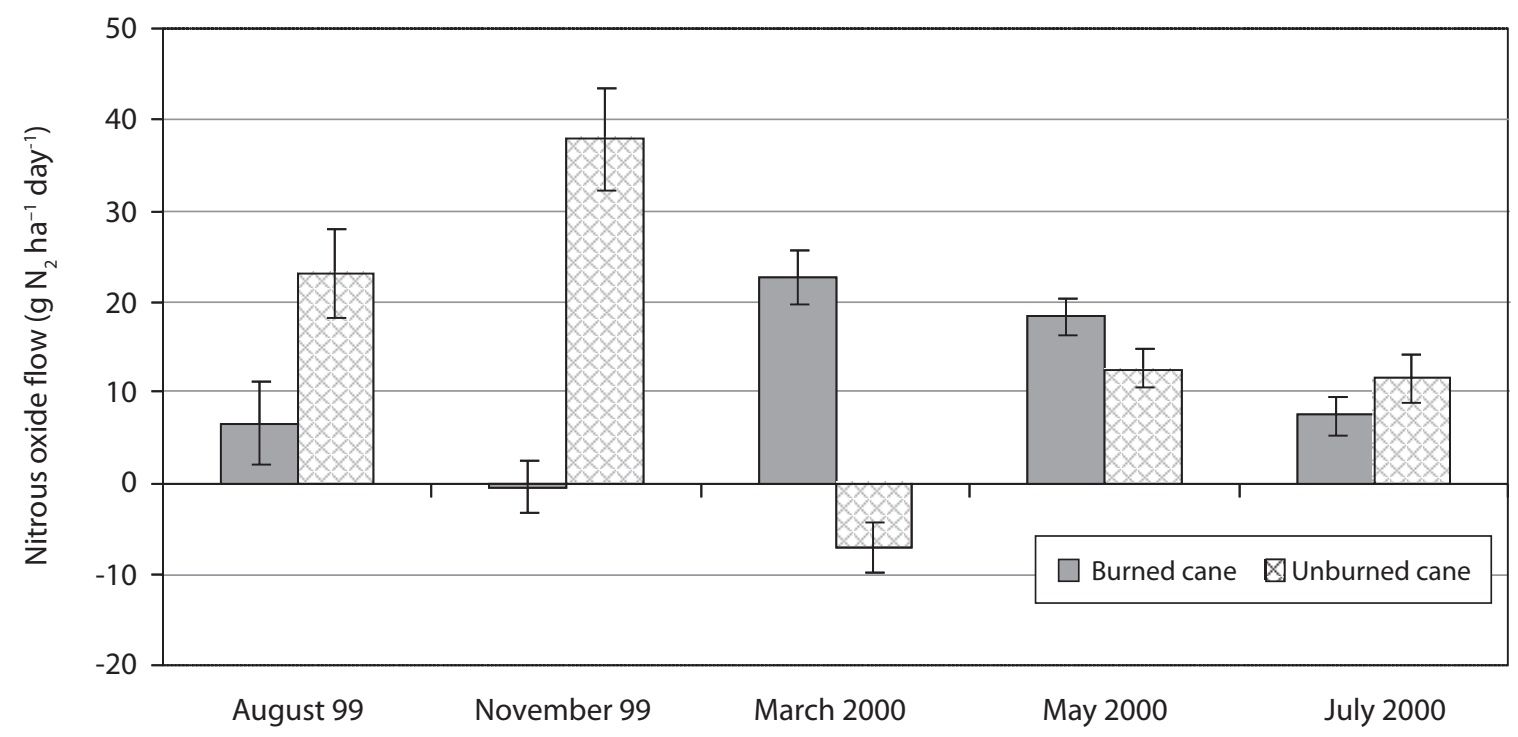

FIGURE 8 Nitrous oxide flow in burned and unburned cane systems. Bars represent the standard error (standard deviation divided by the number of observations).

Few emission factors were measured, especially for nitrous oxide, and seldom for sugarcane residues. To establish national balances, IPCC (IPCC/ Unep/OECD/IEA, 1997) proposes using the following factors: $0.005 \mathrm{~kg}$ of $\mathrm{C}_{-} \mathrm{CH}_{4}$ released per $\mathrm{kg}$ of $\mathrm{C}$, and $0.007 \mathrm{~kg} \mathrm{~N}-\mathrm{N}_{2} \mathrm{O}$ per $\mathrm{kg}$ of $\mathrm{N}$ released in the combustion.

Average vegetal biomass production in the unburned cane system of Situation 1 analyzed was 13.9 t DM/ha. Considering that an equivalent quantity is consumed by fire in the burned cane system, the average release per hectare would be $6 \mathrm{t} \mathrm{C}$ and $43 \mathrm{~kg} \mathrm{~N}$. It is worth reminding that fresh vegetal biomass contains, on average, $430 \mathrm{~g} \mathrm{C}$ and $3.1 \mathrm{~g} \mathrm{~N}$ per $\mathrm{kg}$ of dry matter, i.e., it results in releasing 3 $\mathrm{kg} \mathrm{C}-\mathrm{CH}_{4}$ and $0.3 \mathrm{~kg} \mathrm{~N}-\mathrm{N}_{2} \mathrm{O}$, or yet, $35 \mathrm{~kg} \mathrm{CH}_{4}$ and $0.47 \mathrm{~kg} \mathrm{~N} \mathrm{~N}_{2} \mathrm{O}$. These values may vary according to atmospheric conditions at the time of burning (air humidity, wind intensity) and the sugarcane condition (water and nitrogen content). Calculation is based on the $\mathrm{C} / \mathrm{N}$ ratio that was measured in this study $(\mathrm{C} / \mathrm{N}=51)$, higher than reported by other authors. LIMA et al. (2002), while developing the balance of GHG emissions from burning vegetal residues in Brazil, assumes average $\mathrm{C}$ and $\mathrm{N}$ contents of respectively $42.5 \pm 2.1 \%$ and $1.27 \pm 0.5 \%$
$(\mathrm{C} / \mathrm{N}=33.5)$ for sugarcane residues. Using these values would imply in the emission of almost $2 \mathrm{~kg}$ $\mathrm{N}_{2} \mathrm{O} /$ ha. Upon revising the literature, ANDREAE and MERLET (2001) propose other emission coefficients for burning agricultural residues: $2.7 \mathrm{~g}$ $\mathrm{CH}_{4}$ and $0.07 \mathrm{~g} \mathrm{~N}_{2} \mathrm{O}$ per $\mathrm{kg}$ of dry matter burned. The use of these coefficients results in a higher GHG release: $37.53 \mathrm{~kg} \mathrm{CH}_{4}$ and $0.97 \mathrm{~kg} \mathrm{~N}_{2} \mathrm{O}$. These values, however, are proposed for all agricultural residues (corn straw, cotton residues etc.), which are generally dried up before burning. Therefore, the same authors propose using a factor of $0.21 \pm$ $0.10 \mathrm{~g} \mathrm{~N}_{2} \mathrm{O}$ per kg of burnt dry matter for nitrous oxide when burning savannahs or fields.

Methane emissions, regardless of the calculation method and the data used, vary very little, and are in the 35-38 $\mathrm{kg} \mathrm{CH}_{4} /$ ha range. The same does not apply to nitrous oxide, whose emissions vary a lot: 0.5 to $3 \mathrm{~kg} \mathrm{~N}_{2} \mathrm{O} / \mathrm{ha}$.

\section{Carbon Accounting (Ceq) in the agricultural phase of ethanol production}

Signatories of the UNFCCC - United Nations Framework Convention on Climate Change - predict that the calculation of net emissions should be expressed in $\mathrm{CO}_{2}$ equivalents, considering the 
TABLE 5 Yearly average balance for one hectare of sugarcane field in Situation 1 in $\mathrm{kg}$ Ceq. Negative values indicate a reduction in GHG in Ceq.

\begin{tabular}{|c|c|c|c|c|}
\hline \multirow[t]{2}{*}{ Source } & Burned cane & Unburned cane & $\begin{array}{l}\text { Yearly } \Delta \text { (unburned - } \\
\text { burned cane) }\end{array}$ & $\begin{array}{l}\text { Uncertainty } \\
\text { level }\end{array}$ \\
\hline & \multicolumn{3}{|c|}{ kg Ceq/ha.year } & \\
\hline Stock in vegetal biomass & \multicolumn{3}{|c|}{ temporary stock } & * \\
\hline Stock in soil $0-20 \mathrm{~cm}$ & & & $-1,625$ & * \\
\hline Yearly $\mathrm{CH}_{4}$ flow from soil & -39 & -18 & 21 & ** \\
\hline Yearly $\mathrm{N}_{2} \mathrm{O}$ flow from soil & 323 & 460 & 137 & $* * *$ \\
\hline $\mathrm{CH}_{4}$ flow while burning & $230^{\mathrm{a}}$ & - & -230 & $* *$ \\
\hline $\mathrm{N}_{2} \mathrm{O}$ flow while burning & $140^{\mathrm{b}}$ & - & -140 & $* * * *$ \\
\hline Total & & & $-1,837$ & \\
\hline
\end{tabular}

a Central value of the variation amplitude $220-240 \mathrm{~kg}$ Ceq

${ }^{\mathrm{b}}$ Central value of the variation amplitude $40-240 \mathrm{~kg}$ Ceq.

global warming potential (GWP) of each gas. GWP is a relative measurement, which determines the radiation forcing of a gas, considering $\mathrm{CO}_{2}$ as a reference that is assigned the value of 1 . Based on this concept, the Third IPCC Assessment Report (IPCC, 2001) defined, for GWPs, and for a century-long horizon of 100 GWP years, the values of 23 for methane, and 296 for nitrous oxide. This means that, in terms of radioactive force, one $\mathrm{kg}$ of $\mathrm{CH}_{4}$ or $\mathrm{N}_{2} \mathrm{O}$ is as effective as 23 or $296 \mathrm{~kg}$ of $\mathrm{CO}_{2}$, respectively. Expressed on a $\mathrm{C}-\mathrm{CO}_{2}$ scale, known as Ceq (C equivalent), $1 \mathrm{~kg}$ of $\mathrm{C}-\mathrm{CH}_{4}$ is equivalent to $8.36 \mathrm{~kg}$ of Ceq and $1 \mathrm{~kg}$ of $\mathrm{N}_{2} \mathrm{O}$, to $126.86 \mathrm{~kg}$ Ceq.

From the previously analyzed four destination components of the sugarcane harvest resulting vegetal biomass, it is possible to compare the burned and unburned cane systems over the period of four years under study.

These results clearly show that from the GHG balance point of view, the unburned cane system is more advantageous than the burned cane one, as $1,837 \mathrm{~kg}$ Ceq per year failed to be released to the atmosphere during the period under analysis. However, it is proper to consider the stability of such system. The $\mathrm{C}$ stocked in the vegetal biomass deposited on the soil cannot be considered in this balance, as this compartment is very fragile. Due to the half-life observed of 200-265 days, its interference is restricted mostly to the first two years after the unburned cane harvesting system has been in place. In the next few years, roughly, there is almost a stabilization of the $\mathrm{C}$ stocked in this compartment, since a balance settles between yearly intakes and outputs. The residual vegetal biomass works like a temporary reservoir, which may be quickly exhausted if the inputs drop. However the presence of such compartment is very important, since it is the $\mathrm{C}$ source that keeps stock in a more stable way.

The balance also fails to consider the sugarcane field reform that occurs every 5-7 years, when the inputs are lower. At this time the soil is revolved (ploughed), not only disturbing its superficial layer, but the vegetal residues as well. This specific point of the culture cycle should be studied in more detail. Among the positive effects of the permanent presence of vegetal residues there is the protection against erosion, and the increase of nutrients inputs to the soil (CANELLAS et al., 2003).

From a social standpoint, mechanized harvesting is generally regarded as progress for human health. Sugarcane fields burning causes the release of various gases and potentially hazardous organic compounds such as aromatic polycyclic hydrocarbons (SANTOS et al., 2002), as well as 
the abundant emission of carbonated ashes. Recent medical studies (ARBEX, 2001; CANÇADO et al., 2006; ROSEIRO, 2002) demonstrated the connection between sugarcane burning and the increase in respiratory problems, especially in children. Even though the negative impact of soot (ashes) is quite controversial, it is necessary to admit that it forces the population to clean more frequently their dwellings and swimming pools, increasing water consumption (still considered an inexpensive product in Brazil), which represents a serious problem, especially when the level of water is extremely low.

Among the negative effects attributed to banning sugarcane burning, is the impact on the labor market, constantly discussed in terms of employment. The adoption of the unburned cane system is unavoidable and will result in mechanized harvesting. A recent study by Vieira (2003) in Usina da Barra, the world's largest mill, located in the São Paulo state, producing about 4\% of sugar and 3\% of all the alcohol in Brazil, shows that one harvester replaces 67 persons per hour of operation. On the long run, the burned cane ban will cause 2,117 menial jobs losses, and will create 177 qualified jobs. This net job loss is often pointed out as a major negative effect for banning burning cane. On the other hand, such jobs are of poor quality, constantly criticized as being on the threshold of slave work.

\section{FINAL CONSIDERATIONS}

Unburned sugarcane harvesting and leaving the vegetal biomass on the soil restores a

\section{REFERENCES}

ANDREAE, M. O.; MERLET, P. Emission of trace gases and aerosols from biomass burning. Global Biogeochemical Cycles, v. 15, n. 4, p. 955-966, 2001.

ARBEX, M. A. Avaliação dos efeitos do material particulado proveniente da queima da plantação de cana-deaçúcar sobre a morbidade respiratória na população de Araraquara. 2001. 188 f. Tese - Faculdade de Medicina da Universidade de São Paulo, São Paulo, 2001.

BASANTA, M. V. Dinâmica do nitrogênio na cultura de cana-de-açúcar em diferentes sistemas de manejo de considerable part of the organic matter lost with the burned cane harvest system. The comparison between the two handling systems (burned and unburned cane) shows that preserving the vegetal biomass allows to sequester $\mathrm{C}$ in the studied soils. The analysis of nitrous oxide and methane during burning and over the complete agricultural cycle, also demonstrates the positive effect on the overall balance, in terms of mitigating GHG emissions. Ethanol has been considered as one of the viable alternatives for replacing fossil fuels, which are the major sources of greenhouse gas emissions to the atmosphere and, consequently, of the acceleration in global warming. As for replacement fossil fuels, for an increased environmental benefit, markedly related to global climate changes, it is necessary to produce bioethanol where it provides a better fixation of carbon in the soil, and with lower greenhouse effect gases emissions associated to its productive process. The information summarized in this document stresses the importance of the soil as an extraordinary means to fix carbon dioxide from the atmosphere. Data from a case study show that mechanized sugarcane harvesting provides a net balance of $1.8 \mathrm{Mg} \mathrm{C} / \mathrm{ha} /$ year, where the carbon saved in the soil, due to trash decay, may represent $80-90 \%$ of the total quantity not issued to the atmosphere. In a sustainable biofuel production business, it is increasingly important to adopt conservationist handling practices that involve cleaner production, to reduce the carbon footprint. Such practices, in addition of being environmentally correct, should also be socially and economically viable, as it will add value to Brazilian ethanol destined for exports.

resíduos da colheita. 2004. 82 f. Tese (Doutorado)

- Escola Superior de Agricultura "Luiz de Queiroz", Piracicaba, 2004.

BOWDEN, R. D.; MELILLO, J. M.; STEUDLER, P. A. 1991.

Effects of nitrogen additions on annual nitrous oxides fluxes from temperate Forest soils in the northeastern United States. J. Geophys. Res., 96, p. 9321-9328.

CAMPOS, D. C. de. Potencialidade do sistema de colheita sem queima da cana-de-açúcar para o sequestro de carbono. 2003. 103 f. Tese da Escola Superior de Agri- 
cultura "Luiz de Queiroz" - Universidade de São Paulo, Piracicaba, 2003.

CANÇADO, J. E. D.; SALDIVA, P. H. N.; PEREIRA, L. A. A.; LARA, L. B. L. S.; ARTAXO, P.; MARTINELLI, L. A.; ARBEX, M. A.; ZANOBETTI, A.; BRAGA, A. L. F. 2006. The impact of sugarcane-burning emissions on the respiratory system of children and the elderly. Environmental Health Perspective, Research Triangle Park, v. 114, n. 5, p. 725-729.

CANELLAS, L. P.; VELLOSO, A. C. X.; MARCIANO, C. R.; RAMALHO, J. F. G. P.; RUMJANEK, V. M.; REZENDE, C. E.; SANTOS, G. A. Propriedades químicas de um cambissolo cultivado com cana-de-açúcar, com preservação do palhiço e adição de vinhaça por longo tempo. Revista Brasileira de Ciência do Solo, 27, p. 935-944, 2003.

CEDDIA, M. B.; ANJOS, L. H. C. dos; LIMA, E.; RAVELLI NETO, A.; SILVA, L. A. Sistemas de colheita da canade-açúcar e alterações nas propriedades físicas de um solo podzólico amarelo no Estado do Espírito Santo. Pesquisa Agropecuária Brasileira, Brasília, v. 34, p. 1467-1473, 1999.

CERRI, C. C.; BERNOUX, M.; FELLER, C.; CAMPOS, D. C.; DE LUCA, E. F.; ESCHENBRENNER, V. Canne à sucre et sequestration du carbone. Paris: Académie d'Agriculture de France, Séance du 17 mars, 15 p., 2004.

CONAB - Companhia Nacional de Abastecimento. Disponível em: <http://www.conab.gov.br/conabweb/>. Acesso em: 25 fev. 2008.

DALAL, R. C.; WANG, W.; ROBERTSON, G. P.; PARTON, W. J. Nitrous oxide emission from Australian agricultural lands and mitigation options: a review. Autralian Journal of Soil Research, 41, p. 165-195, 2003.

DOURADO-NETO, D.; TIMM, L. C.; OLIVEIRA, J. C. M.; REICHARDT, K.; BACCHI, O. O. S.; TOMINAGA, T. T.; CÁSSARO, F. A. M. State-space approach for the analysis of soil water content and temperature in a sugarcane crop. Scientia Agricola, Piracicaba, v. 56, n. 4, p. 1215-1221, 1999. Suplemento.

EMBRAPA. Sistema Brasileiro de Classificação de Solos. Empresa Brasileira de Pesquisa Agropecuária. 2. ed. Rio de Janeiro, 2006. 306 p.

FAO. 2006. Guidelines for soil description. Food and Agriculture Organization. 4. ed. Rome, 2006. 109 p.

FAOSTAT. 2007. FAO Statistical databases. Disponível em: $<$ http://faostat.fao.org/site/340/default.aspx>.

FELLER, C. Efeitos da colheita sem queima da cana-deaçúcar sobre a dinâmica do carbono e propriedades do solo. Relatório final do Projeto Fapesp 98/12648-3, Piracicaba, 2001. 146 p.

GALDOS, M. V. Dinâmica do carbono do solo no agrossistema cana-de-açúcar. 2007. 101 f. Tese (Doutorado)
- Escola Superior de Agricultura "Luiz de Queiroz", Piracicaba, 2007.

GAVA, G. J. C.; TRIVELIN, P. C. O.; VITTI, A. C.; OLIVEIRA, M. W. Urea and sugarcane straw nitrogen balance in a soil-sugarcane crop system. Pesquisa Agropecuária Brasileira, Brasília, v. 40, n. 7, p. 689-695, 2005.

GRAHAM, M. H.; HAYNES, R. J.; MEYER, J. H. Soil organic matter content and quality: effects of fertilizer applications, burning and trash retention on a long-term sugarcane experiment in South Africa. Soil Biology and Biochemistry, 34, p. 93-102, 2002.

GRANLI, T.; BOCKMAN, O. C. Nitrous oxide from agriculture. Norwegian Journal of Agricultural Sciences, v. 12, p. 1-128, 1994.

IPCC. 2001. Climate change 2001: The scientific basis. Contribution of working group I to the third assessment report of the intergovernmental panel on climate change. HOUGHTON, J. T.; DING, Y.; GRIGGS, D. J.; NOGUER, M.; VAN DER LINDEN, P. J.; DAI, X.; MASKELL, K.; JOHNSON, C. A. (Eds.). Cambridge University Press, Cambridge, United Kingdom and Nova York, N Y, USA, 881 p.

IPCC/Unep/OECD/IEA. 1997. Revised 1996 IPCC Guidelines for national greenhouse gas inventories: reporting instructions (Volume 1); Workbook (Volume 2); Reference Manual (Volume 3). Paris: Intergovernmental Panel on Climate Change, United Nations Environment Programme, Organization for Economic Co-Operation and Development, International Energy Agency.

LIMA, M. A.; LIGO, M. A. V.; CABRAL, O. M. R.; BOEIRA, R. C.; NEVES, M. C.; PESSOA, M. C. P. Y. 2002. Emissões de gases de efeito estufa na queima de resíduos agrícolas. Relatórios de Referência, Primeiro Inventário Brasileiro de Emissões Antrópicas de Gases de Efeito Estufa. Ministério da Ciência e tecnologia, Embrapa. $82 \mathrm{p}$.

MACEDO, I. C.; JOAQUIM, E. A.; SEABRA, J. E. A.; SILVA, J. E. A. R. Green house gases emissions in the production and use of ethanol from sugarcane in Brazil: The 2005/2006 averages and a prediction for 2020, Biomass and Bioenergy (2008), doi:10.1016/j. biombioe.2007.12.006.

MACEDO, I. C.; NOGUEIRA, L. A. H. Avaliação da expansão da produção de etanol no Brasil. Brasília: Centro de gestão de estudos estratégicos, jul. 2004. 71 p.

MAPA - Ministério da Agricultura Pecuária e Abastecimento. Disponível em: <http://www.agricultura.gov. br/>. Acesso em: 10 dez. 2007.

SANTOS, C. Y. M. dos; AZEVEDO, D. A.; AQUINO NETO, F. R. 2002. Selected organic compounds from biomass burning found in the atmospheric particulate matter 
over sugarcane plantations áreas. Atmospheric Environment, 36, p. 3009-3019.

NOBLE, A. D.; MOODY, P.; BERTHELSEN, S. 2003. Influence of changed management of sugarcane on some soil chemical properties in the humid wet tropics of north Queensland. Australian Journal of Soil Research, 41, p. 1133-1144.

ROBERTSON, F. Sugarcane trash management: consequences for soil carbon and nitrogen - Final report of the project Nutrient Cycling in Relation to Trash Management. Townville: CRC for Sustainable Sugar Production, 2003. 39 p.

RIPOLI, T. C; MOLINA JUNIOR, W. F; RIPOLI, M. L. C. Energy potential of sugarcane biomass in Brazil. Scientia Agricola, 57, p. 677-681, 2000.

ROSEIRO, M. N. V. 2002. Morbidade por problemas respiratórios em Ribeirão Preto-SP, de 1995 a 2001, segundo indicadores ambientais, sociais e econômicos. 170 f. Dissertação - Universidade de São Paulo, Ribeirão Preto, SP.

SCHWEIZER, M. 2000. Variability of factors affecting greenhouse gas fluxes $\left(\mathrm{CO}_{2}, \mathrm{~N}_{2} \mathrm{O}\right.$ and $\left.\mathrm{CH}_{4}\right)$ on a Dark red latossol cultivated with sugarcane (Brazil, São Paulo State). Memore de l'ETH, Suisse. 37p + annexes. Soil Survey Staff. 1999. Keys to soil taxonomy, $5^{\text {th }}$ ed. Blacksburg: Pocahontas Press, 556 p.

TOMINAGA, T. T.; CÁSSARO, F. A. M.; BACCHI, O. O. S.; REICHARDT, K.; OLIVEIRA, J. C. M.; TIMM, L. C.
Variability of soil water content and bulk density in a sugarcane field. Australian Journal of Soil Research, Collingwood, v. 40, p. 605-614, 2002.

THORBURN, P. J.; KEATING, B. A.; ROBERTSON, F. A.; WOOD, A. W. Long-term changes in soil carbon and nitrogen under trash blanketing. Proc. Aust. Soc. Sugarcane Technol., 22, p. 217-224, 2000.

UNICA, 2008. Disponível em: <http://www.portalunica. com.br/portalunicaenglish/?Secão=statistics $>$. Acesso em: 10 maio 2008.

VIEIRA, G. Avaliação do custo, produtividade e geração de emprego no corte de cana-de-açúcar, manual e mecanizado, com e sem queima prévia. 2003. 115 f. Dissertação - Faculdade de Ciências Agronômicas da Unesp, Botucatu, 2003.

WEIER, K. L. Trace gas emissions from a trash blanketed sugarcane field in tropical Australia. In: WILSON, J. R.; HOGARTH, D. M.; CAMPBELL, J. A.; GARSIDE, A. L. Sugar 2000 Symposium: Sugar: research towards efficient and sustainable production, Brisbane: CSIRO Division of tropical crops and pastures, p. 271-272, 2000.

YAMUlKI, S.; GOULDING, K. W. T.; WEBSTER, C. P.; HARRISON, R. M. Studies on $\mathrm{NO}$ and $\mathrm{N}_{2} \mathrm{O}$ fluxes from a wheat field. Atmospheric Environment, v. 29, n. 14, p. 1627-1635, 1995. 